\title{
Using Chemically Treated Organic Recycling Materials to Enhance Freshwater Purification
}

\author{
Agnieszka Bednarek ${ }^{1,2 *}$,Sebastian Szklarek ${ }^{1,2}$, Katarzyna Dziedziczak³, \\ Bogusław Kowalski ${ }^{3}$, Maciej Zalewski ${ }^{1,2}$ \\ ${ }^{1}$ Department of Applied Ecology, Faculty of Biology and Environmental Protection, \\ University of Łódź, Banacha 12/16, 90-264 Łódź, Poland \\ ${ }^{2}$ European Regional Centre for Ecohydrology, Polish Academy of Sciences, \\ Tylna 3, 90-364 Łódź, Poland \\ ${ }^{3}$ Institute for Sustainable Technologies National Research Institute, \\ The Textile Technologies Department in Łódź, \\ Hipoteczna 6, 91-335 Łódź, Poland
}

Received: 17 October 2015

Accepted: 19 March 2016

\begin{abstract}
The greatest source of phosphorus pollution in the freshwater ecosystem is erosion from agricultural areas and point sources. Although this pollution is typically moderated by precipitation and sedimentation, biological and physicochemical methods can be used. The aim of our study was to construct an alternative prototype solution incorporating a filter bed made of suitable recycled phytogenic materials (hemp and harl flax) mixed with chemical compounds $\left(\mathrm{Ca}(\mathrm{OH})_{2}, \mathrm{FeCl}_{3}\right.$, and $\left.\mathrm{Al}_{2}\left(\mathrm{SO}_{4}\right)_{3}\right)$ based on the results of laboratory and field experiments. An $80-90 \%$ reduction was noted for deposits with $\mathrm{Ca}(\mathrm{OH})_{2}$ and $\mathrm{Al}_{2}\left(\mathrm{SO}_{4}\right)_{3}$ compounds, and $42 \%$ for $\mathrm{FeCl}_{3}$ during laboratory studies. The field studies did not provide such a high reduction of phosphates - only $2 \%$ for the $\mathrm{Ca}(\mathrm{OH})_{2}$ deposit and $49 \%$ for the $\mathrm{FeCl}_{3}$ deposit. This could be attributed to variable physical parameters $(\mathrm{pH}$, temperature and dissolved oxygen) and high negative correlation $(r=-0.6296 ; p=0.003)$ with nitrate reduction for the $\mathrm{Ca}(\mathrm{OH})_{2}$ deposit. However, greater reduction was noted when the phosphate concentration exceeded $1 \mathrm{mg} \mathrm{PO}_{4}^{3-} \mathrm{L}^{-1}$ in field experiments.
\end{abstract}

Keywords: phosphorus pollution, organic recycling materials, freshwater purification, dephosphorization

\section{Introduction}

The development of civilization and its accompanying anthropopressure have increased the accumulation of biogenic elements in aquatic ecosystems, which has

*e-mail: agnik@biol.uni.lodz.pl accelerated the eutrophication of water bodies all over the world [1-3], and by doing so increased the production of tides of toxic cyanobacteria [4-5]. There is, therefore, a need to integrate ecohydrology with engineering solutions on the catchment scale to slow the rate of eutrophication [6], with the potential to permanently decrease the content of bioavailable phosphorus in water supplies 
[7-11]. The use of phosphate retention media is one method employed to remove phosphorus pollution. Different materials and chemical compounds can be used for this purpose, for example natural materials (snail shells, tree bark, limestone), industrial by-products (fly ash, acid mine drainage residuals) and manufactured materials (including $\mathrm{Fe}, \mathrm{Al}$, and Ca salts) [12-16]. Binding phosphorus in the sediments of lakes and reservoirs is a common and easy technique to prevent algal blooms, but this solution has a high cost of use and needs large quantities of compounds [17-18]. Moreover, for the development to be sustainable, the solution requires the use of mineral fertilizers [19], which could be also made from the materials used to remove phosphorus pollution from water.

The aim of this study was to evaluate the efficiency of a new type of deposit intended for the removal of phosphorus pollution from streams and for drainage ditches to prevent algal blooms occurring in reservoirs. A prototype device was made to prepare the deposit, consisting of waste materials - harl made from hemp (Cannabis sativa) and flax (Linum sp.) - plus calcium, aluminium, and iron compounds. The produced deposits were tested at laboratory and field scales. To examine the effectiveness of the biodegraded fibrous deposits at removing phosphorus compounds from the water, the conducted study evaluates the efficiency of the chemical deposits at improving the quality of the tested water.

\section{Materials and Methods}

\section{Technological Preparation of the Filter Bed}

A prototype was constructed for the physical and chemical processing of natural fibrous raw materials (mainly agricultural waste) into biodegradable fibrous deposits. In the first processing stage, the prototype device was designed and constructed by defibrating/milling the fibrous material into a particular fraction of about $3 \mathrm{~mm}$ (Figs 1-2.). This stage was necessary because milling the fibrous materials involves significantly disturbing the fibrous structure. The obtained dust product forms a waterabsorbent wall on the surface of the substrate, which is less absorbent than the fibrous form. In the fibrous form, appropriate defibrating/milling increases the degree of potential water absorption by up to four times, resulting in the loss of vital hydrophysical properties. This method allows for the level of defibration to be changed based on the nature of the fibrous material and its intended use. The fibrous substrate can be obtained from various materials within the unified fraction, while the dust fractions from the process are stored separately for further processing in other applications (e.g., in agrotechnics).

The present interdisciplinary study resulted in the design of an innovative method of defibrating and a new model laboratory device that can be used for experimental purposes. In this innovative method, raw material is defibrated at a low speed, which gradually increases to maximum speed as the mass of fibrous molecules decreases. This approach ensures minimal dust in the defibrated mass, which ensures no negative impact on its desired properties. The apparatus that can be used for the preparation of the filter bed has been registered with the Polish Patent Office under No. P.401776. It needs to be stated that the process of wet defibration followed by desiccation is not a competitive option in the pulp and paper industry because of its particularly high energy consumption, which makes the process a few times more expensive.

The second preparation stage was the impregnation of defibrated fibrous material with calcium, aluminium, and iron compounds in their colloidal form. These compounds are inexpensive, easily available, and readily form insoluble compounds with phosphorus.

The use of a colloidal form of metal compounds in preparing the deposit is a modern method that has been made possible by the use of an appropriate fibrous structure. This structure allows for the formation and monitoring of hydrophysical properties that determine the permeability of the deposit and the effective "confinement" of the colloidal form of the metal compounds within it. A prototype chemical device was used to ensure the even mixing of fibrous material with appropriate phosphorusbinding chemical compounds (Fig. 3).

After the impregnation process, the prepared deposit was used in laboratory and field experiments.

\section{Laboratory Experiment}

All laboratory experiments were conducted in $2.2 \mathrm{~m}$ pipes ( $0.12 \mathrm{~m}$ diameter) connected to $200 \mathrm{~L}$ barrels with a pollution mixture. Artificial sewage was made using POLIDAP ammonium phosphate fertilizer containing $18 \%$ nitrogen $(\mathrm{N})$ as ammonium and $46 \%$ phosphorus $(\mathrm{P})$ as $\mathrm{P}_{2} \mathrm{O}_{5}$ (Fig. 4). The deposits in the pipes were prepared according to the following steps using the devices given in Figs 1 and 3. First, $10 \mathrm{~kg}$ of the fibrous substrate was passed through a $4 \mathrm{~mm}$ mesh sieve, and $20 \mathrm{~L}$ of $\mathrm{Ca}$

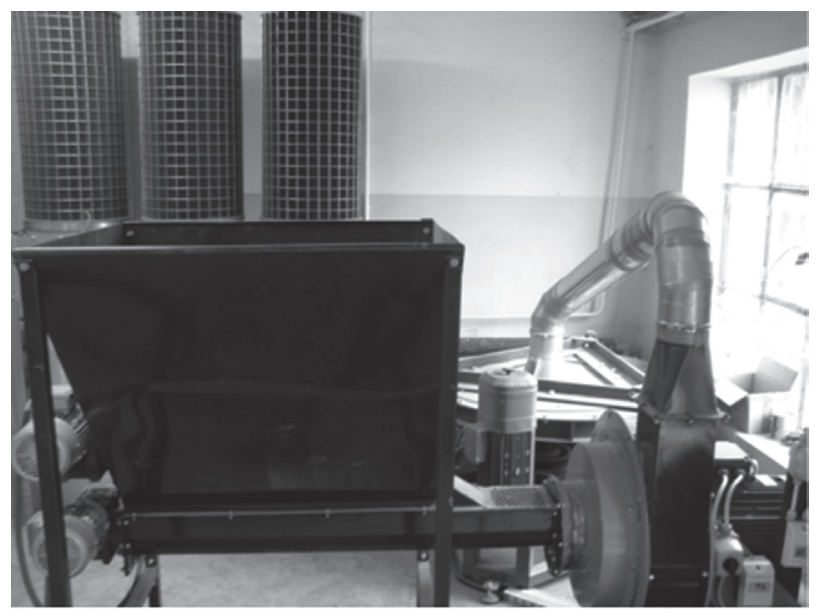

Fig. 1. Device for fragmentation of the fibrous raw materials to the appropriate fractions. 

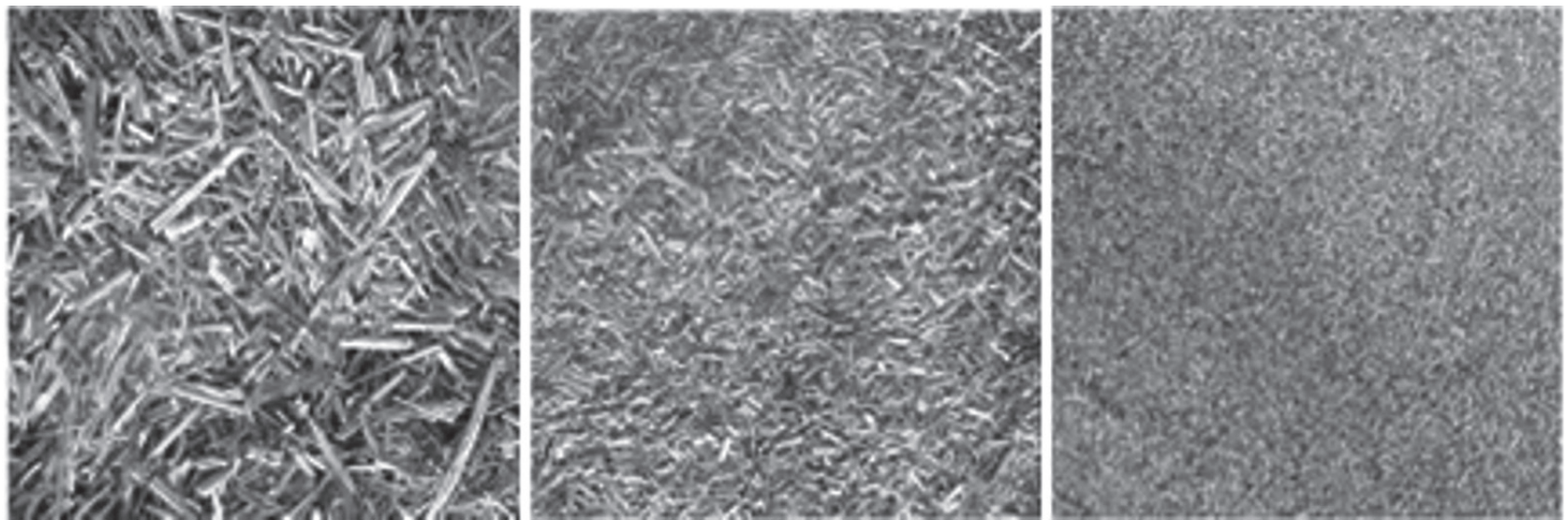

Fig. 2. Fractions of fibrous raw materials.
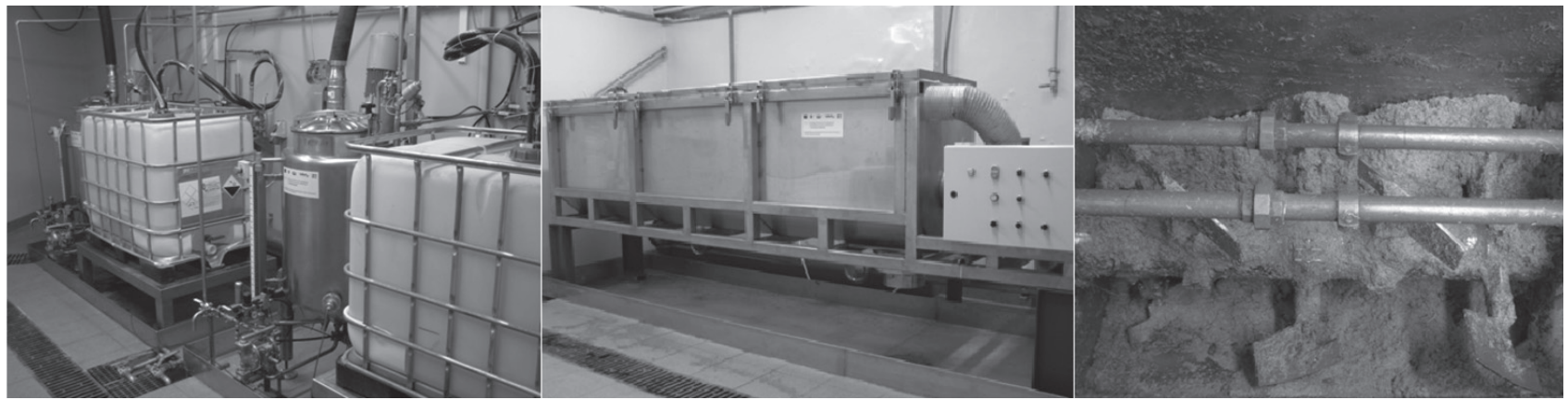

Fig. 3. Tanks for the preparation of chemical solutions used to impregnate raw fibrous materials (left); impregnation process of fibrous raw materials in the reactor (middle); impregnation process of fibrous raw materials in the reactor (right).

$(\mathrm{OH}) 2, \mathrm{FeCl}_{3}$, or $\mathrm{Al}_{2}\left(\mathrm{SO}_{4}\right)_{3}$ was prepared at the required concentration. The solution and the fibrous substrate were then introduced to the reaction vessel and mixed for two hours.

Experimental reactors were built for the laboratory tests (Fig. 4). They consisted of fibrous deposits with chemical compounds that form insoluble salts with phosphorus: one based on $\mathrm{Ca}(\mathrm{OH})_{2}$ (two different phosphate inflows with concentrations of $5.87 \mathrm{mg} \mathrm{PO}_{4}^{3-} \mathrm{L}^{-1}$ and $12.20 \mathrm{mg}$ $\mathrm{PO}_{4}^{3-} \mathrm{L}^{-1}$ ), the second on $\mathrm{FeCl}_{3}$ (three different concentrations: $1 \%, 5 \%$, and $10 \%$ of $\mathrm{FeCl}_{3}$ ), and the third on $\mathrm{Al}_{2}\left(\mathrm{SO}_{4}\right)_{3}$ (three different concentrations: $6.8 \%, 13.6 \%$,

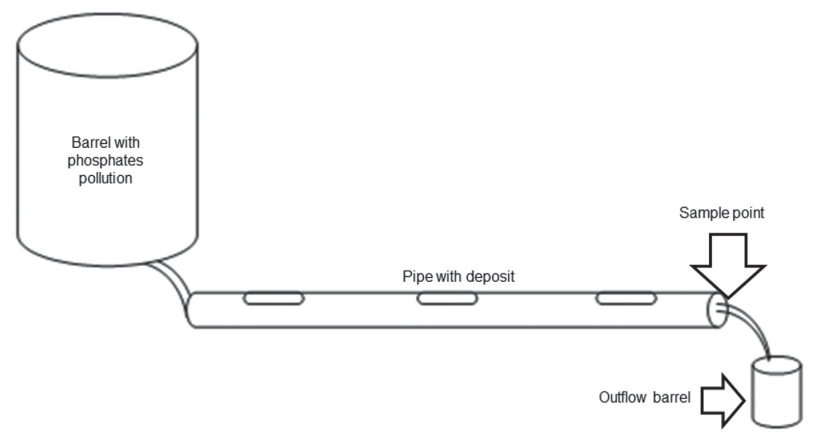

Fig. 4. Laboratory experiment scheme for all tested deposits. and $27.2 \%$ of $\left.\mathrm{Al}_{2}\left(\mathrm{SO}_{4}\right)_{3}\right)$. The experiments continued for 40-46 days (Table 1). Water samples were taken manually (typically twice a week).

\section{Field Experiment}

Initial field trials were conducted in Tresta Rzadowa (Tomaszow province; $51^{\circ} 46^{\prime} \mathrm{N}, 20^{\circ} 00^{\prime} \mathrm{E}$ ), at the Department of Applied Ecology field station located $500 \mathrm{~m}$ from the northeastern shore of Sulejow Reservoir. A $20 \mathrm{~kg}$ deposit of fibrous substrate with $\mathrm{Ca}(\mathrm{OH})_{2}$ was put into each of 10 jute bags and placed at the bottom of the $20 \mathrm{~m}$-long outflow from the fishpond at $2 \mathrm{~m}$ intervals (Fig. 5). The experiment continued for 98 days. Water samples were taken manually before and after the treatment zone. Samples were taken twice a week until day 69 , and then once a week until the end of the experiment (Table 1). No specific permission was required because these locations/activities and field studies did not involve endangered or protected species.

The second field experiment was carried out in the city of Łódź (central Poland) on the Sokolowka River $\left(51^{\circ} 48^{\prime} \mathrm{N}, 19^{\circ} 27^{\prime} \mathrm{E}\right)$. A $10 \mathrm{~kg}$ of deposit with $\mathrm{FeCl}_{3}$ was put into each of 10 jute bags and placed at the bottom of the $50 \mathrm{~m}$ section of the river at $5 \mathrm{~m}$ intervals (Fig. 6). Samples were taken once a week and the experiment was conducted for 51 days (Table 1). No specific permission 


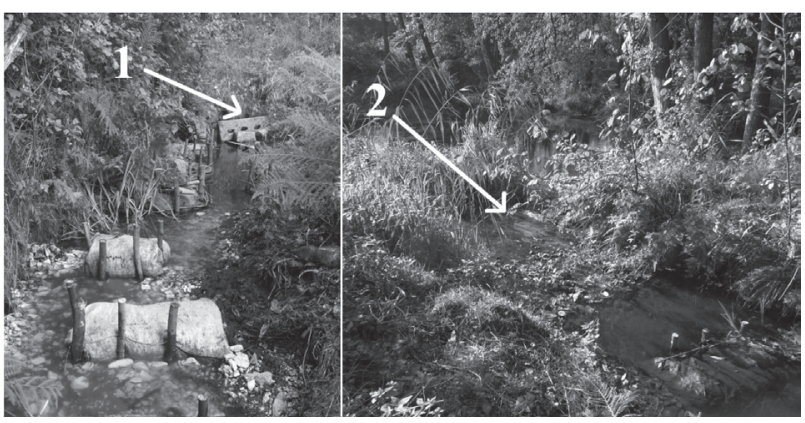

Fig. 5. Tresta field experiment with $\mathrm{Ca}(\mathrm{OH})_{2}$ deposit at the outflow from a fish pond. Sample points: 1 - outflow from fish pond, 2 - at the end of the deposit zone.

was required for these locations/activities and field studies did not involve endangered or protected species.

\section{Physico-Chemical Analysis}

YSI Professional Plus was used to measure the physical parameters of the water in situ: $\mathrm{pH}$, temperature, and dissolved oxygen (DO). The concentrations of selected ions (phosphates and nitrates) were analyzed using a Dionex ion chromatograph with a cation column (CG18, IonPac CS18, CSRS-ULTRA II) and an anion column (AG22, IonPac AS22, ASRS ULTRA II). The systems were operated in isocratic elution at $30^{\circ} \mathrm{C}$ at a flow rate of $1 \mathrm{~mL} \mathrm{~min}{ }^{-1}$. Combined standards were used for ion identification (Dionex Corporation).

\section{Results}

\section{Laboratory Experiment}

The highest average $\mathrm{pH}$ (9.35) was measured in deposits with $\mathrm{Ca}(\mathrm{OH})_{2}$ in the laboratory, followed by

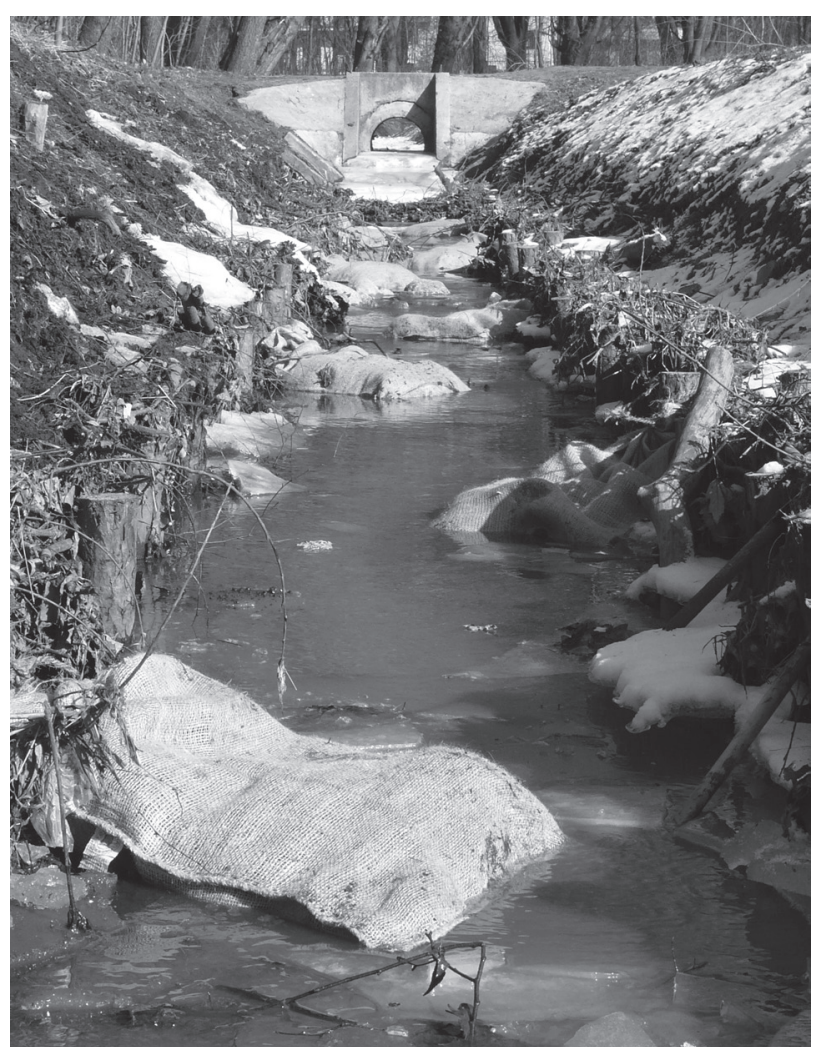

Fig. 6. The Sokolowka field experiment with the $\mathrm{FeCl}_{3}$ deposit placed in the urban river.

$\mathrm{pH}=7.5$ for the $\mathrm{FeCl}_{3}$ field experiment. In the other experiments, $\mathrm{pH}$ ranged from 6.3 to 6.5 (Table 2). The temperature remained steady between 19.5 and $21.0^{\circ} \mathrm{C}$ in all laboratory experiments but was $11.9^{\circ} \mathrm{C}$ during the $\mathrm{FeCl}_{3}$ field experiment (Table 2). The DO level was found to be similar in the laboratory tests, with $5.75 \mathrm{mg} \mathrm{L}^{-1}$ for $\mathrm{Ca}(\mathrm{OH})_{2}$ and $5.91 \mathrm{mg} \mathrm{L}^{-1}$ for $\mathrm{Al}_{2} \mathrm{SO}_{4}$, while the $\mathrm{FeCl}_{3}$ deposits were found to be $1.27 \mathrm{mg} \mathrm{L}^{-1}$ in the laboratory and $7.68 \mathrm{mg} \mathrm{L}^{-1}$ in the field (Table 2).

Table 1. Characteristics of the analyzed deposits and duration of experiments with the frequency of sampling.

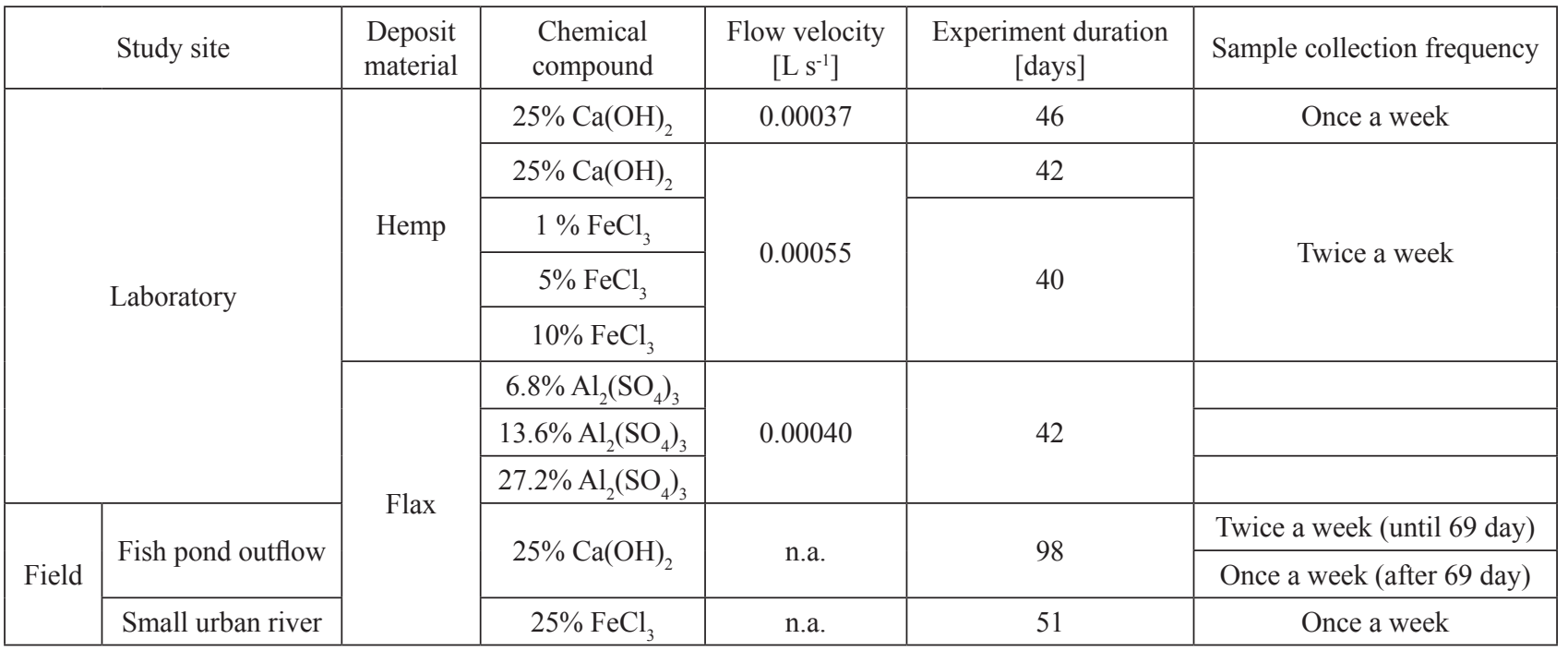


Table 2. Average physical parameters measured in the laboratory (inside the deposit) and field tests (inside the purification zone).

\begin{tabular}{|c|c|c|c|c|c|}
\hline \multirow{2}{*}{$\begin{array}{c}\text { Average of measurement } \\
\text { parameters }( \pm \mathrm{SD})\end{array}$} & \multicolumn{3}{|c|}{ Laboratory experiments } & \multicolumn{2}{c|}{ Field experiments } \\
\cline { 2 - 6 } & $\mathrm{Ca}(\mathrm{OH})_{2}$ & $\mathrm{FeCl}_{3}$ & $\mathrm{Al}_{2} \mathrm{SO}_{4}$ & $\mathrm{Ca}(\mathrm{OH})_{2}$ & $\mathrm{FeCl}_{3}$ \\
\hline $\mathrm{pH}$ & $9.35 \pm 1.01$ & $6.30 \pm 0.98$ & $6.50 \pm 1.15$ & $6.5 \pm 0.42$ & $7.5 \pm 0.34$ \\
\hline Temperature $\left[{ }^{\circ} \mathrm{C}\right]$ & $19.5 \pm 0.5$ & $21.0 \pm 0.4$ & $20.0 \pm 0.25$ & n.a. & $11.9 \pm 3.77$ \\
\hline DO $\left[\mathrm{mg} \mathrm{L}^{-1}\right]$ & $5.75 \pm 0.80$ & $1.27 \pm 0.21$ & $5.91 \pm 0.30$ & n.a. & $7.68 \pm 1.44$ \\
\hline
\end{tabular}

n.a. - not analyzed

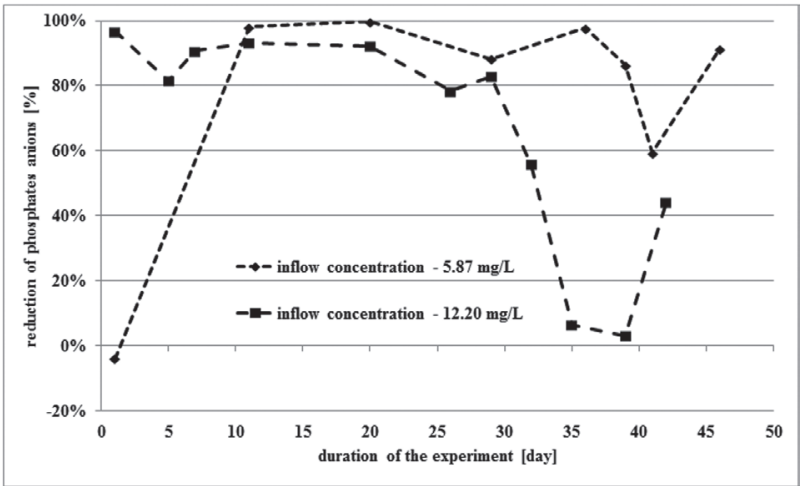

Fig. 7. The percentage reduction of phosphate ion concentration $\mathrm{PO}_{4}^{3-}\left(\mathrm{mg} \mathrm{L}^{-1}\right)$ for the $\mathrm{Ca}(\mathrm{OH})_{2}$ deposit.
The chemical deposit based on calcium hydroxide was found to work more efficiently with the lower inflow of phosphates. The average reduction at an inflow of $5.87 \mathrm{mg} \mathrm{L}^{-1}$ was $90 \%$, compared to $71 \%$ for the higher inflow of $12.20 \mathrm{mg} \mathrm{L}^{-1}$ (Table 3). Both deposits demonstrated a decrease in efficiency around the $40^{\text {th }}$ day of the experiment (Fig. 7).

In order to estimate the ability of iron(III) chloride to reduce phosphate levels, three different concentrations were used. The highest efficiency was noted for the 5\% $\mathrm{FeCl}_{3}$ deposit (the medium tested concentration). The deposit with a $10 \%$ concentration demonstrated an average reduction of about $22 \%$, while no reduction was reported for the deposit treated with $1 \% \mathrm{FeCl}_{3}$ (Table 3). All analysed deposits with $\mathrm{FeCl}_{3}$ released phosphates on the

Table 3. Reduction in phosphate content by the different deposits observed under laboratory and field conditions with statistical analysis.

\begin{tabular}{|c|c|c|c|c|c|c|c|c|c|c|}
\hline \multirow{2}{*}{\multicolumn{2}{|c|}{ Study site }} & \multirow{2}{*}{$\begin{array}{c}\text { Raw } \\
\text { material }\end{array}$} & \multirow{2}{*}{$\begin{array}{l}\text { Chemical } \\
\text { compound }\end{array}$} & \multirow{2}{*}{$\begin{array}{c}\text { Reduction } \\
\text { of } \\
\text { phosphates }\end{array}$} & \multicolumn{2}{|c|}{ Before deposit } & \multicolumn{2}{|c|}{ After deposit } & \multicolumn{2}{|c|}{$\begin{array}{l}\text { Anova } \\
\text { Kruskal-Wallis } \\
\text { results }\end{array}$} \\
\hline & & & & & $\begin{array}{c}\text { Average } \\
\text { inflow } \\
\text { concentration } \\
{\left[\mathrm{mg} \mathrm{PO}_{4}{ }^{3-} \mathrm{L}^{-1}\right]}\end{array}$ & $\begin{array}{l}\text { Standard } \\
\text { deviation }\end{array}$ & $\begin{array}{c}\text { Average } \\
\text { inflow } \\
\text { concentration } \\
{\left[\mathrm{mg} \mathrm{PO}_{4}{ }^{3-} \mathrm{L}^{-1}\right]}\end{array}$ & $\begin{array}{l}\text { Standard } \\
\text { deviation }\end{array}$ & $\mathrm{H}$ & $\mathrm{p}$ \\
\hline \multirow{8}{*}{\multicolumn{2}{|c|}{ Laboratory }} & \multirow{5}{*}{$\begin{array}{l}\text { Hemp } \\
\text { flax }\end{array}$} & $\begin{array}{c}25 \% \\
\mathrm{Ca}(\mathrm{OH})_{2}\end{array}$ & $90 \%$ & 5.87 & 9.47 & 0.59 & 0.75 & 13.9839 & 0.0002 \\
\hline & & & $\begin{array}{c}25 \% \\
\mathrm{Ca}(\mathrm{OH})_{2}\end{array}$ & $71 \%$ & 12.20 & 5.97 & 3.58 & 3.61 & 11.8847 & 0.0006 \\
\hline & & & $1 \% \mathrm{FeCl}_{3}$ & $-4 \%$ & 12.20 & 5.97 & 12.71 & 4.56 & 0.0269 & 0.8696 \\
\hline & & & $\begin{array}{c}5 \% \\
\mathrm{FeCl}_{3}\end{array}$ & $42 \%$ & 12.20 & 5.97 & 7.06 & 4.02 & 6.0636 & 0.0138 \\
\hline & & & $10 \% \mathrm{FeCl}_{3}$ & $22 \%$ & 12.20 & 5.97 & 9.46 & 3.86 & 1.9932 & 0.1580 \\
\hline & & \multirow{5}{*}{ Harl flax } & $\begin{array}{c}6.8 \% \\
\mathrm{Al}_{2}\left(\mathrm{SO}_{4}\right)_{3}\end{array}$ & $83 \%$ & 0.85 & 0.11 & 0.15 & 0.17 & 77.1199 & 0.0000 \\
\hline & & & $\begin{array}{c}13.6 \% \\
\mathrm{Al}_{2}\left(\mathrm{SO}_{4}\right)_{3}\end{array}$ & $56 \%$ & 0.85 & 0.11 & 0.38 & 1.11 & 53.5617 & 0.0000 \\
\hline & & & $\begin{array}{c}27.2 \% \\
\mathrm{Al}_{2}\left(\mathrm{SO}_{4}\right)_{3}\end{array}$ & $81 \%$ & 0.85 & 0.11 & 0.16 & 0.21 & 71.1730 & 0.0000 \\
\hline \multirow{2}{*}{ Field } & $\begin{array}{l}\text { Fish pond } \\
\text { outflow }\end{array}$ & & $\begin{array}{c}25 \% \\
\mathrm{Ca}(\mathrm{OH})_{2}\end{array}$ & $2 \%$ & 0.19 & 0.26 & 0.19 & 0.18 & 0.0885 & 0.7666 \\
\hline & $\begin{array}{l}\text { Small urban } \\
\text { river }\end{array}$ & & $25 \% \mathrm{FeCl}_{3}$ & $49 \%$ & 0.42 & 0.51 & 0.21 & 0.24 & 1.1797 & 0.2774 \\
\hline
\end{tabular}




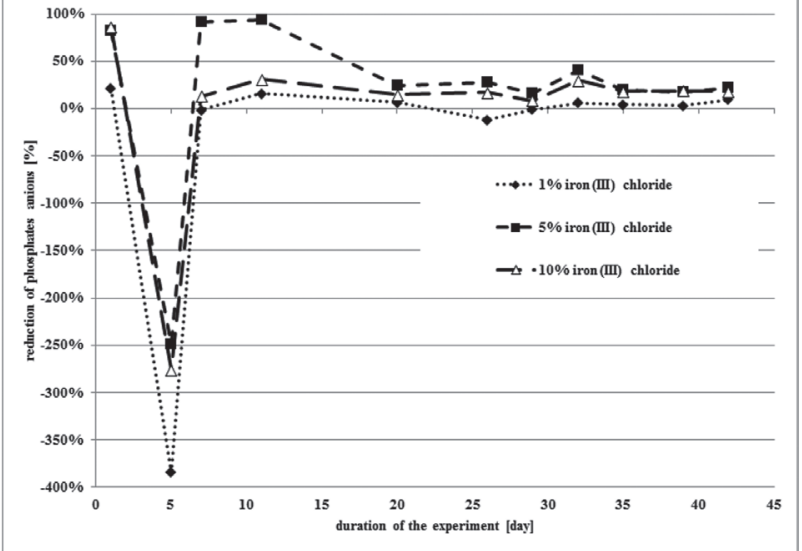

Fig. 8. The percentage of the reduction of phosphate ion concentration $\mathrm{PO}_{4}{ }^{3-}\left(\mathrm{mg} \mathrm{L}^{-1}\right)$ for deposits with $\mathrm{FeCl}_{3}$.

$5^{\text {th }}$ day of the experiment, and demonstrated the greatest efficiency on the $11^{\text {th }}$ day of the experiment (Fig. 8).

Three concentrations of aluminum were also examined. The highest reduction $(83 \%)$ was noted for the lowest concentration, of $6.8 \% \mathrm{Al}_{2}\left(\mathrm{SO}_{4}\right)_{3}$ (Table 3). A similar reduction $(81 \%)$ was obtained for $27.2 \% \mathrm{Al}_{2}\left(\mathrm{SO}_{4}\right)_{3}$, while $13.6 \% \mathrm{Al}_{2}\left(\mathrm{SO}_{4}\right)_{3}$ was only found to have $56 \%$ efficiency (Table 3). A day-to-day plot of the efficiency of treatment (Fig. 9) indicates that the deposit with lowest concentration had the most stable results throughout the whole experiment, with efficiency falling below $80 \%$ only after the day 38. A similar fall was reported for $27.2 \%$ $\mathrm{Al}_{2}\left(\mathrm{SO}_{4}\right)_{3}$. For both the highest and lowest concentrations, the starting efficiency was low - even below $0 \%$ for $13.6 \%$ $\mathrm{Al}_{2}\left(\mathrm{SO}_{4}\right)_{3}$ (Fig. 9).

\section{Field Trials}

The Tresta field experiment was conducted first. The average reduction of phosphate ions was $2 \%$, with a 0.16 $\mathrm{mg} \mathrm{L}^{-1}$ average inflow rate (Table 3 ). In addition, a $30 \%$ mean reduction of nitrate concentration was observed across the purification zone, from $12.18 \mathrm{mg} \mathrm{L}^{-1}$ at the inflow to $8.53 \mathrm{mg} \mathrm{L}^{-1}$ at the outflow. A day-by-day analysis (Fig. 10) indicates that the reduction of nitrates was high, while phosphate reduction was low or even not observed.

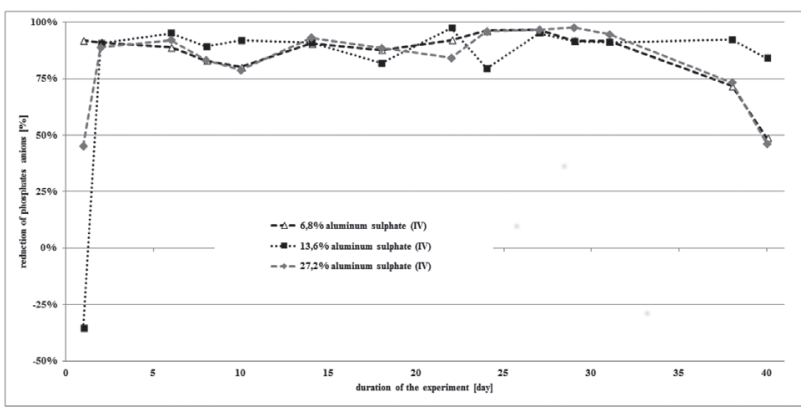

Fig. 9. The percentage reduction of phosphate ion concentration $\mathrm{PO}_{4}^{3-}\left(\mathrm{mg} \mathrm{L}^{-1}\right)$ for the deposit of $\mathrm{Al}_{2} \mathrm{SO}_{4}$.

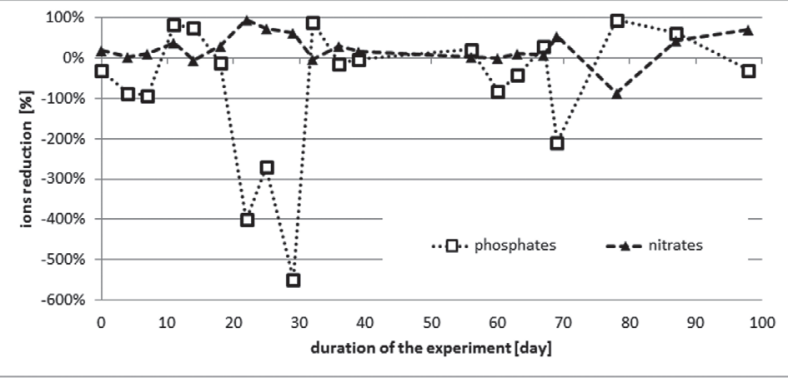

Fig. 10. The changing levels of phosphate and nitrate ions before and after filtration in the Tresta field experiment.

Statistical analysis revealed a strong negative correlation $(\mathrm{r}=-0.6296 ; \mathrm{p}=0.003)$ between the reduction of both ions (Fig. 11). In addition, strong reduction (86\%) was noted on day 11, when a high level of phosphates was measured (1.24 $\mathrm{mg} \mathrm{PO}_{4}^{3-} \mathrm{L}^{-1}$, Fig. 10).

The second set of field experiments was conducted in the Sokolowka, an urban river in Łódź. Jute bags with an $\mathrm{FeCl}_{3}$ deposit were placed across a one-meter width of the river bed. Samples were taken before and after the treatment zone. However, due to the flow being more varied, this experiment was only continued for 58 days (shorter than the Tresta trials).

In this case, a $49 \%$ reduction of phosphates was noted (from $0.41 \mathrm{mg} \mathrm{L}^{-1}$ to $0.21 \mathrm{mg} \mathrm{L}^{-1}$ ) (Table 3). Nitrate

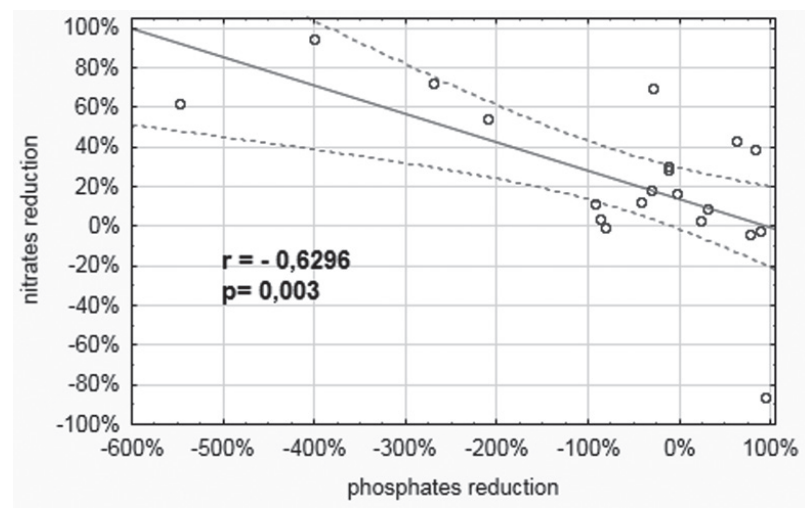

Fig. 11. Spearman correlation between phosphate and nitrate reduction in the Tresta field experiment.

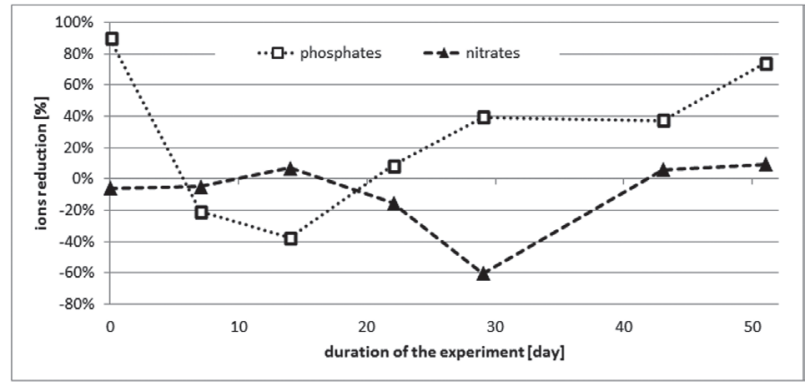

Fig. 12. The changing levels of phosphate and nitrate ions in the Sokolowka River before and after filtration. 
reduction was not observed $\left(10.77 \mathrm{mg} \mathrm{L}^{-1}\right.$ before the zone and $11.18 \mathrm{mg} \mathrm{L}^{-1}$ after). Only a few days with reduction (Fig. 12). High reduction of phosphates $(90 \%)$ was noted on the first day of the experiment, when high inflow occurred (1.4 $\left.\mathrm{mg} \mathrm{PO}_{4}{ }^{3-} \mathrm{L}^{-1}\right)$ (Fig. 12).

\section{Discussion}

Most of the P loading in the Baltic Sea in 2000 originated from point sources (56\% of the total load), with municipalities being the major contributor. Of the remaining 44\%, the majority (around $80 \%$ ) originated from agricultural activities [20]. Despite extensive work to decrease nutrient loading in the Baltic, fulfilling the goals of current legislation and international agreements (e.g., the EU Marine Strategy Framework Directive, the Urban Wastewater Treatment Directive, the Nitrates Directive, and the Water Framework Directive) without further reductions in nutrient discharge seems to be impossible [20]. Therefore, the suite of P-remediation measures must therefore be expanded to include new methods that employ P-sorbing materials. These P-sorbents fall into three groups according to their origin: natural materials, industrial by-products, and manufactured materials [21]. The materials may also be classified according to their chemical composition as follows: those containing metals (mostly $\mathrm{Fe}$ and $\mathrm{Al}$ ), those containing soluble divalent earth metals $(\mathrm{Ca}, \mathrm{Mg})$, and mixtures of the two [12]. Several studies have shown that some materials are capable of removing $\mathrm{P}$ from household wastewater or agricultural runoff, but more studies are needed to optimize the design of filter beds intended for field conditions [12].

Many successful attempts have been made to reclaim reservoirs suffering increased eutrophication, either by limiting the supply of sources of nutrients (especially phosphorus) or by removing them. One such example is that of Lake Constance on the border of Germany, Austria, and Switzerland, where in 1980-2007 control of phosphorus input decreased its concentration to background levels, and with it the chlorophyll concentration and phytoplankton population [22]. However, it should be noted that reclamation based only on reducing the supply of phosphorus is a long process, often due to the load that has already been bound by phytoplankton and bottom sediments within the water body. Therefore, to effectively recover water reservoirs as quickly as possible, it is necessary to apply methods aimed at removing the accumulated stock. So far, the methods used to remove excess phosphorus from surface waters can be divided into two groups: chemical (sediment precipitation) and phytoremediation (accumulation in plant biomass).

Compounds based on salt are the best known methods for removing phosphate pollutants from surface water. They rely on the direct application of selected iron(II) sulphate or chloride, for example, in the processing of pulp, clay (mostly sulphate), or calcium carbonate. The precipitation of phosphorus from deep water is based on the application of a substance which, during sedimentation, coagulates suspended solids into lumps on which phosphorus absorbance takes place. However, the use of this method is limited to the purification of water bodies such as ponds and lakes, as these methods involve expensive reactants and increase the salinity of treated wastewater, and result in the accelerated corrosion of equipment and the production of a large amount of sludge [23].

PIX, PAX, Phoslock, and Sinobent are widely known substances used for treating surface water contaminated with harmful phosphorus compounds. Their biggest drawbacks, however, are the high cost of their use and the need for large quantities to be used in natural ecosystems $[18,24-25]$. The purpose of the study was to design an apparatus for the removal of phosphorus compounds from contaminated freshwater in the most efficient manner possible, at the lowest possible consumable cost and with the least technical requirements. To fulfil these requirements, the proposed solution incorporates fibre deposits of waste materials. It requires little technical skill to produce and can be constructed cheaply where the natural fibrous waste that is used as the raw material is plentiful. From the ecological point of view, it is also important that the fibrous deposit may be used both in water courses and in lakes and ponds. Hence the use of fibrous, biodegradable chemical deposits to block excessive quantities of phosphates from fields and restrict their flow into surface water would reduce eutrophication and improve the ecological status of water as required by the Water Framework Directive [26].

In order to understand the functions of the bodies of water there is a need to understand the processes occurring both in sediments and in the water column and the interaction between them during the retention and release of phosphorus [27]. The deposits presented in this article, composed of defibrated biodegradable waste material (hemp and harl flax) mixed with chemical compounds (contents of calcium, iron, or aluminum ions) bound phosphates from water column could be used as fertilizer after saturation with $\mathrm{P}$ [28].

The use of various calcium materials and compounds for phosphate precipitation is a common method, mainly because of their low cost and ease of handling [10,28]. The deposit of calcium presented in this study allowed between $71 \%$ and $90 \%$ reduction of phosphate concentration (Table 3), which corresponds with the range obtained in other studies (75-98\%) [29-31]. The lower efficiency observed during the second laboratory experiment with the higher phosphate inflow (Table 3 and Fig. 7) may be caused by the low $\mathrm{Ca} / \mathrm{P}$ ratio [30]. The field experiment at the outflow of a fish pond did not provide such a great reduction of phosphates as noted in the laboratory (Table 3 ). Only $2 \%$ of phosphate reduction observed in the field study (Table 3 ) might be caused by the different $\mathrm{pH}$ levels present between field and laboratory experiments. Other studies have shown that the $\mathrm{pH}$ has a significant impact on the efficiency of phosphate absorption by Ca ions [10, 30]. Correlation analyses indicate that the phosphate reduction 
had a high negative correlation $(\mathrm{r}=-0.6296)$ with nitrate reduction (Fig. 11), suggesting that the low level of phosphate reduction observed in the field experiment could also be caused by the influence of calcium ions on denitrification [32].

Iron compounds could also be used for phosphate absorption from a water column [33]. Iron chloride deposits demonstrated the lowest phosphorus removal efficiency in the laboratory study (Table 3 ). The best $43 \% \mathrm{PO}_{4}^{3-}$ reduction was noted for the deposit with $5 \% \mathrm{FeCl}_{3}$. Although this reduction was half what could be achieved, it could be much worse with a low Fe/P ratio - even below 10\% [3435]. The low DO level (Table 2) could be another factor that affects the low reduction in laboratory studies [34-36]. The efficiency measured during the field experiment was found to be similar (49\%) to the lab results for $5 \% \mathrm{FeCl}_{3}$ (Table 3), despite the use of a higher $\mathrm{FeCl}_{3}$ concentration. This might be due to the higher variability of parameters, such as $\mathrm{pH}, \mathrm{DO}$, and temperature, affecting phosphate absorption by iron ions [34-35] in the field experiment (Table 2). Aluminum sulphate was the last compound to be mixed with deposit material. A high phosphorus removal rate of about $90 \%$ was observed (Table 3), which corresponds with results ranging from 80 to $99 \%$ noted in other studies [37-39]. The lower P reduction demonstrated by the $13.6 \% \mathrm{Al}_{2} \mathrm{SO}_{4}$ deposit was caused by the released phosphates in the first days of the experiment (Fig. 9). The reasons for this loss are unclear and further investigation is needed to shed light on them. The optimum $\mathrm{pH}$ and $\mathrm{Al} / \mathrm{P}$ ratio might also have contributed to this high reduction of phosphate content [39].

Two factors might influence the obtained results. While $\mathrm{P}$ appears in inorganic and organic forms under field conditions, laboratory experiments mostly use inorganic P. Secondly, sufficient contact time between the filter material and the flow solution is likewise a crucial point in developing $P$ filters [12].

The removal efficiency of phosphates provided by Fe, $\mathrm{Ca}$, and $\mathrm{Al}$ depends mainly on the physical parameters ( $\mathrm{pH}, \mathrm{DO}$, and temperature) and also the $\mathrm{Fe} / \mathrm{P}, \mathrm{Ca} / \mathrm{P}$, or $\mathrm{Al} / \mathrm{P}$ ratios $[30,34-35,37]$. The ratio of the mentioned ions to phosphorus could be easily changed and controlled in streams and drainage ditches by applying tested deposits. The achieved level of phosphate reduction, combined with the low cost of producing the deposit using the new device (about $\$ 80$ per ton of deposit) and the use of waste materials, makes the technology widely applicable and complementary to other methods for reducing phosphate pollution and preventing cyanobacterial blooms in reservoirs [40-43]. Another feature that is extremely important from the point of view of sustainable development is that the chemical deposits are formed only from natural, biodegradable fibrous raw materials. Hence, after a filter has degraded, it can then be used as fertilizer itself, which is an excellent source of phosphorus and organic compounds to increase the humification of the soil.

\section{Acknowledgements}

The authors are grateful for the financial support given by NCBiR (No. 14006106/2009 Geowlokna: Development of a model geofibrous, biodegradable, biological deposit for reclaiming nitrogen and phosphorus in threatened areas of the agricultural landscape).

\section{References}

1. KIEDRZYŃSKA E., KIEDZRZYŃSKI M., URBANIAK M., MAGNUSZEWSKI A., SKŁODOWSKI M., WYRWICKA A., ZALEWSKI M. Point sources of nutrient pollution in the lowland river catchment in the context of the Baltic Sea eutrophication. Ecological Engineering 70, 337, 2014.

2. JING L., AO H., HUANG X., XIONG X., WU C., LIU J. Water environment characteristics at Taige CanalTaihu Lake: a comparative study on interaction between chlorophyll a and environmental variables. Polish Journal of environmental studies, 24 (3), 1031, 2015.

3. ULRICH A.E., MALLEY D.F., WATTS P.D. Lake Winnipeg Basin: Advocacy, challenges and progress for sustainable phosphorus and eutrophication control. Science of the Total Environment, 542 (B), 1030, 2016.

4. DOLMAN A.M., RÜCKER J., PICK F. R., FASTNER J., ROHRLACK T., MISCHKE U., WIEDNER C. Cyanobacteria and cyanotoxins: The influences of nitrogen versus phosphorus. Plos One 7 (6), e38757, 2012.

5. GĄGAŁA I., IZYDORCZYK K., SKOWRON A., KAMECKA-PLASKOTA D., STEFANIAK K., KOKOCIŃSKI M., MANKIEWICZ-BOCZEK J. Appearance if toxigenic cyanobacteria in two Polish lakes dominated by Microcystis aeruginosa and Planktothrix agardii and environmental factor influence. Ecohydrology \& Hydrobiology 10 (1), 25, 2010.

6. ZALEWSKI M., Ecohydrology and hydrologic engineering: regulation of hydrology-biota intereactions for sustainability. Journal of Hydrologic Engineering, 20 (1), A4014012, 2015.

7. KIEDRZYŃSKA E., KIEDRZYŃSKI M., URBANIAK M., MAGNUSZEWSKI A., SKŁODOWSKI M., WYRWICKA A., ZALEWSKI M. Point sources of nutrient pollution in the lowland river catchment in the context of the Baltic Sea eutrophication. http://dx.doi.org/10.1016/j. ecoleng.2014.06.010 Ecological Engineering 70, 337, 2014.

8. KĘDZIORA A., NEGUSSIE Y. N., ASRES T. M., ZALEWSKI M. Shaping of an agricultural landscape to increase water and nutrient retention. Ecohydrology \& Hydrobiology 11 (3-4), 205, 2011.

9. LU S.Y., WU F.C., LU Y.F., XIANG C.S., ZHANG P.Y., JIN C.X. Phosphorus removal from agricultural runoff by constructed wetland. Ecological Engineering 35, 402, 2009.

10. VOHLA C., KÕIV M., BAVOR J., CHAZARENC F., MANDER Ü. Filter material for phosphorus removal from wastewater in treatment wetlands - A review. Ecological Engineering 37, 70, 2011.

11. GU D., ZHU X., VONGSAY T., HUANG M., SONG LI., HE Y. Phosphorus and Nitrogen Removal Using Novel Porous Bricks Incorporated with Wastes and Minerals. Polish Journal of Environmental Studies 22 (5), 1349, 2013.

12. KLIMESKI A., CHARDON W.J., TURTOLA E., UUSITALO R. Potential and limitations of phosphate retention 
media in water protection: A process-based review of laboratory and field-scale tests. Agricultural and Food Science, 21 (3), 206, 2012.

13. KLIMESKI A., UUSITALO R., TURTOLA E. Screening of $\mathrm{Ca}$-and Fe-rich materials for their applicability as phosphateretaining filters. Ecological Engineering, 68, 143, 2014.

14. PENN C., MCGRATH J., BOWEN J., WILSON S. Phosphorus removal structures: A management option for legacy phosphorus. Journal of Soil and Water Conservation, 69 (2), 51A, 2014.

15. WANG Y., TNG K. H., WU H., LESLIE G., WAITE T.D. Removal of phosphorus from wastewaters using ferrous salts - A pilot scale membrane bioreactor study. Water Research, 54, 140, 2014.

16. DITTRICH M., GABRIEL O., RUTZEN C., KOSCHEL R. Lake restoration by hypolimnetic $\mathrm{Ca}(\mathrm{OH})_{2}$ treatment: Impact on phosphorus sedimentation and release from sediment. Science of the Total Environment 409, 1504, 2011.

17. MEIS S., SPEARS B. M., MABERLY S. C., O'MALLEY M. B., PERKINS R. G. Sediment amendment with Phospholock in Clatto Reservoir (Dundee. UK): Investigating changes in sediment elemental composition and phosphorus fraction. Journal of Environment Management 93 (1), 185, 2012.

18. GOŁDYN R., PODSIADŁOWSKI S., DONDAJEWSKA R., KOZAK A. The sustainable restoration of lakes towards the challenges of the Water Framework Directive. Ecohydrology \& Hydrobiology 14 (1), 68, 2014.

19. HUKARI S., HERMANN L., NÄTTROP A. From wastewater to fertilisers - Technical overview and critical review of European legislation governing phosphorus recycling. Science of the Total Environment, 542, 1127, 2016.

20. HELCOM. Eutrophication in the Baltic Sea - An integrated thematic assessment of the effects of nutrient enrichment in the Baltic Sea region. Helsinki Commission. Executive Summary. Baltic Sea Environment Proceeding. No. 115A. 2009.

21. CUCARELLA V., RENMAN G. Phophorus sorption capacity of filter materials used for on-site wastewater treatment determined in batch experiments - a comparative study. Journal of Environmental Quality 38, 381, 2009.

22. SCHINDLER D.W. The dilemma of controlling cultural eutrophication of lakes. Proc Biol Sci 279, 4322, 2012.

23. BERNACKA J., KURBIEL J., PAWŁOWSKA L. Usuwanie związków biogennych ze ścieków miejskich (Removal of nutrients from municipal sewage). Institute of Environmental Protection. Warsaw. 1995 [In Polish].

24. GOŁDYN R., DONDAJEWSKA R., KOWALCZEWSKAMADURA K. Wpływ nowych preparatów chemicznych na ograniczenie wydzielania fosforu $\mathrm{z}$ osadów dennych (The influence of new chemicals on the reduction of ortophosphorus release from bottom sediments) In: Malina G. (Ed.) Rekultywacja i Rewitalizacja Terenów Zdegradowanych (Reclamation and Revitalization of Demoted Areas). PZITS. Poznan. 53, 2010 [In Polish].

25. DUNALSKA J.A., GROCHOWSKA J., WIŚNIEWSKI G., Napiórkowska-Krzebietke J. Can we restore badly degraded urban lakes? Ecological Engineering 82, 432, 2015.

26. WATER FRAMEWORK DIRECTIVE. (Directive 2000/60/ EC of the European Parliament and of the Council of 23 October 2000 establishing a framework for Community action in the field of water policy). OJL 327. 22 December 2000. $1,2000$.

27. SØNDERGAARD M., JENSEN J., JEPPESEN E. Role of sediment and internal loading of phosphorus in shallow lakes. Hydrobiologia 506 -509, 135, 2003.
28. DE-BASHAN L.E., BASHAN Y. Recent advances in removing phosphorus from wastewater and its future use as fertilizer (1997-2003). Water Research 38, 4222, 2004.

29. CUCARELLA V., ZALESKI T., MAZUREK R., RENMAN G. Fertilizer Potential of Calcium-Rich Substrates Used for Phosphorus Removal from Wastewater. Polish Journal of Environmental Studies 16 (6), 817, 2007

30. HOSNI K., BEN MOSSUA S., CHACI A., BEN AMOR M. The removal of $\mathrm{P}_{\mathrm{O}}^{43-}$ by calcium hydroxide from synthetic wastewater: optimization of operating conditions. Desalination 223, 337, 2008.

31. ASHEKUZZAMAN S. M., JIAN J-Q. Study on the sorption-desorption-regeneration performance of $\mathrm{Ca}$-. $\mathrm{Mg}$ - and CaMg-based layered double hydroxides for removing phosphate from water. Chemical Enginneering Journal 246, 97, 2014.

32. FERNÁNDEZ-NAVA Y., MARAÑÓN E., SOONS J., CASTRILLÓN L. Denitrification of wastewater containing high nitrate and calcium concentration. Bioresource Technology 99 (17), 7976, 2008

33. PENG J., WANG B., SONG Y., YUAN P., LIU Z. Adsorption and release of phosphorus in the surface sediment of a wastewater stabilization pond. Ecological Engineering 31, 92, 2007.

34. ZHANG Z., WANG Y., LESLIE G.L., WAITE T.D. Effect of ferric and ferrous iron addition on phosphorus removal and fouling in submerged membrane bioreactors. Water Research 69, 210, 2015.

35. ZHANG M., ZHENG K., JIN J., YU X., QIU L., DING S., LU H., CAI J., ZHENG P. Effects of $\mathrm{Fe}(\mathrm{II}) / \mathrm{P}$ ratio and $\mathrm{pH}$ on phosphorus removal by ferrous salt and approach to mechanisms. Separation and Purification Technology 118, $801,2013$.

36. AHLGREN J., REITZEL K., DE BRABANDERE H., GOGOLL A., RYDIN E. Release of organic P forms from lake sediments. Water Research 45, 565, 2011.

37. REITZEL K., HANSEN J., ANDERSEN F., HANSEN K. S., JENSEN H. S. Lake restoration by dosing aluminum relative to mobile phosphorus in the sediment. Environmental Science \& Technology 39 (11), 4134, 2005.

38. RODRIGUEZ I.R., AMRHEIN C., ANDERSON M.A. Reducing dissolved phosphorus to the Salton Sea with aluminum sulfate. Hydrobiologia 604 (1), 37, 2005.

39. XIE J., LIN Y., LI C., WU D., KONG H. Removal and recovery of phosphate from water by activated aluminum oxide and lanthanum oxide. Powder Technology 269, 351, 2015.

40. CHENG W.P., CHI F.H., YU R.F. Effect of phosphate on removal of humic substances by aluminum sulfate coagulant. Journal of Colloid and Interface Science 272, 153, 2004.

41. ZALEWSKI M. Ecohydrology for implementation of the EU water framework directive. Proceedings of the ICE-Water Management 164 (8), 375, 2010.

42. GĄGAŁA I., IZYDORCZYK K., JURCZAK T., PAWEŁCZYK J., DZIADEK J., WOJTAL-FRANKIEWICZ A., JÓŹWIK A., JASKULSKA A., MANKIEWICZ-BOCZEK J. Role of Environmental Factors and Toxic Genotypes in the Regulation of Microcystins - Producing Cyanobacterial Blooms. Microb. Ecol. 67, 465, 2014.

43. SZULC B., JURCZAK T., SZULC K., KACZKOWSKI Z. The influence of the ecohydrological rehabilitation in the cascade of the Arturówek reservoirs in Łódź (Central Poland) on the cyanobacterial and algae blooming. Oceanological and Hydrological Studies 44 (2), 236, 2015. 